\title{
PENGARUH MEDIA PICK ME TERHADAP PERKEMBANGAN KECERDASAN VERBAL LINGUISTIK ANAK USIA DINI
}

\author{
Nidia Mufidati ${ }^{1}$, Ratno Abidin ${ }^{2}$, Naili Sa'ida ${ }^{3}$ \\ Universitas Muhammadiyah Surabaya \\ Email: nidiamufidati11@gmail.com ${ }^{1}$, ratno.abidin@fkip.um-surabaya.ac.id ${ }^{2}$, \\ nelysaida@gmail.com ${ }^{3}$
}

\begin{abstract}
ABSTRAK
Media pick me merupakan hasil pengembangan dari media gambar seri yang dikemas menarik menggunakan benda-benda replika yang berada disekitar anak, sehingga media pick me merupakan suatu inovasi media pembelajaran. Penelitian ini bertujuan untuk mengetahui pengaruh media pick me dalam mengembangkan kecerdasan verbal linguistik (kemampuan bercerita), yang menjawab bagaimana pengaruh media pick me dalam mengembangkan kecerdasan verbal linguistik (kemampuan bercerita) sebagai rumusan masalah dalam penelitian ini. Metodologi penelitian mengunakan jenis penelitian kuantitatif dengan desain one group pretest posttest karena hanya menggunakan satu kelas sebagai sampel penelitian dan adanya tahapan pretest, posttest sebagai proses pemerolehan data. Teknik analisis data menggunakan uji Wilcoxon yang memiliki kriteria jika Thitung $<$ Ttabel maka $\mathrm{H} \alpha$ diterima. Hasil analisis data memperoleh nilai $\mathrm{T}$ hitung 0 dan nilai $\mathrm{T}$ tabel 40, karena $0<40$ maka hasil penelitian menyatakan bahwa terdapat pengaruh penggunaan media pick me terhadap perkembangan kecerdasan verbal linguistik (kemampuan bercerita).
\end{abstract}

Kata kunci: kecerdasan verbal linguistik; kemampuan bercerita; media pick me.

\begin{abstract}
Pick me media is the result of the development of the drawing media series that is packaged interestingly using replica objects that are around the child, so the pick me media is an innovative media learning. This research aims to determine the influence of pick me media in developing verbal linguistic intelligence (storytelling ability), which answers how is the influence of pick me media in developing verbal linguistic intelligence (storytelling ability) as a formulation of the problem in this research. The research methodology used quantitative research type with one group pretest, posttest stage because it used only one class as research sample and pretest stage, posttest as data acquisition process. Data analysis technique used Wilcoxon test that has criteria if T-count $<\mathrm{T}$-table then $\mathrm{H} \alpha$ is accepted. The result of data analysis got $\mathrm{T}$ arithmetic value 0 and $\mathrm{T}$-table value 40 , because $0<40$ hence result of research stated that there is influence of pick me media to develop verbal linguistic intelligence (ability of storytelling).
\end{abstract}

Keyword: linguistic verbal intelligence; storytelling ability; media pick me

\section{PENDAHULUAN}

Kecerdasan verbal linguistik adalah kecerdasan yang berkembang pada aspek bahasa seperti membaca, menulis, bercerita dan mendengarkan. Jasmine (2012:17) mengungkapkan bahwa Kecerdasan verbal linguistik mewujudkan dirinya dalam kata-kata, baik dalam tulisan maupun lisan. Orang yang memiliki kecerdasan ini juga memiliki keterampilan auditori yang sangat tinggi, dan mereka belajar melalui mendengar, mereka gemar membaca, menulis dan berbicara dan suka bercengkrama dengan kata-kata. Kecerdasan verbal linguistik merupakan kecerdasan yang penting untuk dikembangkan karena bahasa merupakan alat komunikasi yang tidak dapat 
digantikan oleh apapun dalam kehidupan.

Perkembangan verbal linguistik mencakup kemampuan menulis, membaca, berbicara yang didalamnya terdapat kemampuan bercerita. Ketika anak berusia 4-5 tahun dalam perkembangan kemampuan menulis, anak mampu menghubungkan tulisan sederhana dengan suatu simbol. Dalam perkembangan kemampuan membaca anak mampu membaca gambar yang memiliki kata yang sederhana. Pada perkembangan kemampuan berbicara anak mampu menyebutkan banyak nama binatang, makanan, tanaman dan benda-benda disekitarnya, anak mampu berbicara dengan kalimat yang sederhana namun penggucapannya sudah jelas, anak mampu bercerita tentang kejadiankejadian yang perna dilihat, serta anak mampu menceritakan bendabenda yang perna dia temui sebelumnya. Terjadinya sebuah hambatan dalam setiap proses perkembangan anak merupakan suatu hal yang biasa, namun hal ini perlu menjadi sebuah perhatian supaya penyebab dari hambatan tersebut dapat segera ditemukan dan permasalahan pada perkembangan anak dapat dengan cepat diatasi.

Proses komunikasi merupakan salah satu hal yang penting bagi kehidupan manusia dimana dalam berkomunikasi kita dapat bertanya, menjawab, mengungkapkan ide atau gagasan serta saling bertukar pengalaman yang biasa disebut dengan bercerita. Namun untuk aktif berkomunikasi setiap orang harus belajar terlebih dahulu untuk memiliki keberanian mengatakan sesuatu yang ada dalam pikirannya. Usia dini merupakan masa yang tepat untuk mengembangkan segala kemampuan termasuk kemampuan berkomunikasi. Jika sejak usia dini anak sudah terbiasa terlibat dalam proses komunikasi baik dengan orang dewasa maupun teman sebayanya maka dewasa nanti anak akan memiliki sikap terbuka dan mudah untuk berkomunikasi.

Pada hakikatnya anak usia dini juga termasuk makhluk sosial jadi secara otomatis anak memiliki kemauan untuk mengatakan apa yang ada dalam pikirannya akan tetapi tidak memiliki keberanian yang cukup. Berdasarkan observasi awal di kelompok A TK Aisyiyah 33 Surabaya terlihat anak-anak masih belum mampu berkomunikasi antara teman sebaya dalam satu kelas dengan baik. Ditandai dengan sikap malu-malu serta kebingungan yang ditunjukkan oleh peserta didik saat ditunjuk untuk bercerita didepan kelas. Anak juga belum mampu mengungkapkan pendapat serta menceritakan kembali apa yang sudah diceritakan oleh guru sebelumnya. Hal ini tentu akan menjadi salah satu permasalah untuk pendidik sebab keberhasilan pencapaian perkembangan anak usia dini ditentukan oleh pembelajaran yang diberikan oleh pendidiknya.

Lembaga pendidikan TK Aisyiyah 33 surabaya pada kelompok A sebanyak 29 peserta didik dari total 
keseluruhan sebanyak 36 peserta didik mengalami kesulitan saat bercerita didepan kelas. Oleh karena itu perkembangan kecerdasan verbal linguistik utamanya dalam kemampuan bercerita sangat perlu dikembangkan dikelas ini. Mengingat kemampuan bercerita merupakan alat komunikasi yang tidak dapat dipisahkan dari kehidupan manusia.

Permasalah yang dialami anak usia dini di Kelompok A TK Aisyiyah 33 Surabaya mendorong penulis untuk dapat mengatasi permasalahan tersebut dengan menerapkan media pick me yang merupakan pembaruan dari media gambar seri dengan tujuan untuk menstimulasi anak usia dini dalam mengingat pengalamannya dan menceritakan didepan kelas. Sehingga dapat mengembangkan kecerdasan verbal linguistik terutama pada kemampuan bercerita anak usia dini. Media ini dapat menjadi salah satu solusi media alternatif yang afektif untuk digunakan dalam proses pembelajaran pengembangkan kemampuan bercerita pada anak usia dini. Media pick me merupakan suatu inovasi media pembelajaran yang memiliki fungsi sebagai salah satu media peraga, dengan desain yang baru dan menarik.

Adapun tujuan penelitian ini adalah mengetahui pengaruh media pick me terhadap perkembangan kecerdasan verbal linguistik dalam kemampuan bercerita pada anak usia dini. Sesuai dengan tujuan penelitian maka terdapat pengaruh media pick me terhadap perkembangan kecerdasan verbal linguistik dalam kemampuan bercerita pada anak usia dini sebagai hipotesis penelitian.

\section{METODE PENELITIAN}

\begin{tabular}{llr}
\multicolumn{1}{c}{ Jenis penelitian } & yang \\
digunakan adalah penelitian & \\
kuantitatif dengan desain & penelitian \\
Pre-experimental One Group Pre-
\end{tabular} Pre-experimental One Group PreTest - Post-Test. Menurut Noor (2015:115) cara menerapkan desain ini adalah dengan melakukan satu kali pengukuran di depan (pre-test) sebelum adanya perlakuan (treatment) dan setelah itu dilakukan pengukuran lagi (post-test). Perlakuan yang diberikan diyakini akan berpengaruh positif. Teknik pengumpulan data mengunakan observasi dan dokumentasi, Observasi adalah suatu metode pengukuran data untuk mendapatkan data primer, yaitu dengan cara melakukan pengamatan langsung secara seksama dan sistematis, dengan menggunakan alat indra (indra mata, telinga, hidung, tangan dan pikiran), Mustafa (2009:94). Penelitian ini menggunakan teknik observasi berbagai aspek perkembangan yang berhubungan dengan kecakapan sedangkan instrumen yang digunakan dalam penelitian ini menggunakan check list (Daftar cocok). Indikator observasi kecerdasan verbal linguistik dalam kemampuan bercerita dapat dilihat pada tabel sebagai berikut: 
Tabel 1

Lembar Observasi

\begin{tabular}{|c|c|c|c|c|c|c|}
\hline \multirow[t]{2}{*}{$\mathrm{KD}$} & \multirow[t]{2}{*}{ Indikator } & \multirow[t]{2}{*}{ Butir } & \multicolumn{4}{|c|}{ Penilaian } \\
\hline & & & 1 & 2 & 3 & 4 \\
\hline \multirow{6}{*}{$\begin{array}{l}3.11 \text { memahami } \\
\text { bahasa ekspresif } \\
\text { (mengungkapkan } \\
\text { bahasa secara verbal } \\
\text { dan non verbal) }\end{array}$} & \multirow[t]{2}{*}{$\begin{array}{l}\text { 3.11.1 ekspresi } \\
\text { wajah (senang, } \\
\text { marah, sedih) }\end{array}$} & $\begin{array}{l}\text { Dapat } \\
\text { menunjukkan } \\
\text { berbagai ekspresi }\end{array}$ & & & & \\
\hline & & $\begin{array}{l}\text { Dapat } \\
\text { menyesuaikan } \\
\text { mimik wajah } \\
\text { dengan cerita yang } \\
\text { disampaikan }\end{array}$ & & & & \\
\hline & \multirow[t]{2}{*}{$\begin{array}{l}3.11 .5 \text { tanya jawab } \\
\text { tentang } \\
\text { keterangan/informasi }\end{array}$} & $\begin{array}{l}\text { Dapat mengajukan } \\
\text { pertanyaan pada } \\
\text { teman yang telah } \\
\text { bercerita }\end{array}$ & & & & \\
\hline & & $\begin{array}{l}\text { Dapat menjawab } \\
\text { pertanyaan yang } \\
\text { diajukan oleh } \\
\text { teman }\end{array}$ & & & & \\
\hline & \multirow[t]{2}{*}{$\begin{array}{l}\text { 3.11.6 mengulang } \\
\text { kalimat yang sudah } \\
\text { didengar }\end{array}$} & $\begin{array}{l}\text { Dapat } \\
\text { menceritakan } \\
\text { kembali cerita } \\
\text { yang telah } \\
\text { didengar }\end{array}$ & & & & \\
\hline & & $\begin{array}{l}\text { Dapat menarik } \\
\text { kesimpulan cerita } \\
\text { yang telah } \\
\text { didengar }\end{array}$ & & & & \\
\hline \multirow{3}{*}{$\begin{array}{l}4.11 \text { menunjukkan } \\
\text { kemampuan } \\
\text { berbahasa ekspresif } \\
\text { (mengungkapkan } \\
\text { bahasa secara verbal } \\
\text { dan non verbal) }\end{array}$} & \multirow[t]{2}{*}{$\begin{array}{l}4.11 .5 \text { bercerita } \\
\text { tentang pengalaman } \\
\text { anak }\end{array}$} & $\begin{array}{l}\text { Dapat mengingat } \\
\text { pengalaman } \\
\text { sebagai bahan } \\
\text { untuk bercerita } \\
\end{array}$ & & & & \\
\hline & & $\begin{array}{l}\text { Dapat } \\
\text { menceritakan } \\
\text { pengalaman secara } \\
\text { sederhana }\end{array}$ & & & & \\
\hline & $\begin{array}{l}\text { 4.11.6 melengkapi } \\
\text { kalimat yang sudah } \\
\text { dimulai guru }\end{array}$ & $\begin{array}{l}\text { Dapat melengkapi } \\
\text { kalimat yang } \\
\text { dimulai guru } \\
\text { dengan benar }\end{array}$ & & & & \\
\hline
\end{tabular}

Ketercapaian indicator yang dimuat dalam lembar observasi dijelaskan dalam rubric penilaian sebagai berikut:

Tabel 2

Rubrik Penelitian

\begin{tabular}{|c|c|c|c|}
\hline No & Butir & Kriteria & Keterangan \\
\hline 1 & Dapat menunjukkan berbagai &
\end{tabular}




\begin{tabular}{|c|c|c|c|}
\hline & \multirow[t]{4}{*}{ ekspresi } & & $\begin{array}{l}\text { menunjukkan } 5 \text { ekspresi } \\
\text { dasar (bahagia, sedih, } \\
\text { kecewa, sakit, marah) }\end{array}$ \\
\hline & & 众余众 & $\begin{array}{l}\text { Anak mampu } \\
\text { menunjukkan } 4 \text { ekspresi } \\
\text { dasar }\end{array}$ \\
\hline & & $\hat{\aleph}$ & $\begin{array}{l}\text { Anak mampu } \\
\text { menunjukkan } 3 \text { ekspresi } \\
\text { dasar }\end{array}$ \\
\hline & & $\hat{\aleph}$ & $\begin{array}{l}\text { Anak mampu } \\
\text { menunjukkan } 2 \text { ekspresi } \\
\text { datar }\end{array}$ \\
\hline \multirow[t]{4}{*}{2} & \multirow[t]{4}{*}{$\begin{array}{l}\text { Dapat menyesuaikan mimik } \\
\text { wajah dengan cerita yang } \\
\text { disampaikan }\end{array}$} & 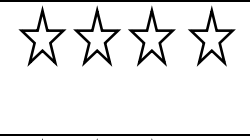 & $\begin{array}{l}\text { Anak mampu } \\
\text { menyesuaikan ekspresi } \\
\text { dengan isi cerita }\end{array}$ \\
\hline & & 文 & $\begin{array}{l}\text { Anak membutuhkan } \\
\text { bantuan dalam } \\
\text { menyesuaikan ekspresi } \\
\text { saat bercerita }\end{array}$ \\
\hline & & & $\begin{array}{l}\text { anak mampu berekspresi } \\
\text { namun tidak sesuai } \\
\text { dengan cerita yang } \\
\text { disampaikan }\end{array}$ \\
\hline & & $\hat{n}$ & $\begin{array}{l}\text { Anak belum mampu } \\
\text { menyesuaikan ekspresi } \\
\text { saat bercerita }\end{array}$ \\
\hline \multirow[t]{4}{*}{3} & \multirow[t]{4}{*}{$\begin{array}{l}\text { Dapat mengajukan pertanyaan } \\
\text { pada teman yang telah bercerita }\end{array}$} & 众众昘 & $\begin{array}{l}\text { Anak mampu merespon } \\
\text { cerita dengan mengajukan } \\
\text { beberapa pertanyaan }\end{array}$ \\
\hline & & $\hat{4} \boldsymbol{\alpha}$ & $\begin{array}{l}\text { Anak mampu mengajukan } \\
\text { pertanyaan namun kurang } \\
\text { sesuai dengan isi cerita }\end{array}$ \\
\hline & & & $\begin{array}{l}\text { Anak perlu bantuan dalam } \\
\text { mengajukan pertanyaan }\end{array}$ \\
\hline & & $\hat{w}$ & $\begin{array}{l}\text { Anak belum mampu } \\
\text { mengajukan pertanyaan }\end{array}$ \\
\hline \multirow[t]{4}{*}{4} & \multirow[t]{4}{*}{$\begin{array}{l}\text { Dapat menjawab pertanyaan } \\
\text { yang diajukan oleh teman }\end{array}$} & 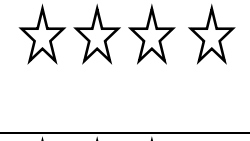 & $\begin{array}{l}\text { Anak mampu menjawab } \\
\text { pertanyaan teman sesuai } \\
\text { dengan isi cerita }\end{array}$ \\
\hline & & 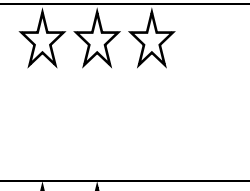 & $\begin{array}{l}\text { Anak mampu menjawab } \\
\text { pertanyaan teman, namun } \\
\text { kurang sesuai dengan isi } \\
\text { cerita }\end{array}$ \\
\hline & & $\hat{h} \boldsymbol{4}$ & $\begin{array}{l}\text { Anak membutuhkan } \\
\text { bantuan dalam menjawab } \\
\text { pertanyaan }\end{array}$ \\
\hline & & $\hat{\aleph}$ & $\begin{array}{l}\text { Anak belum mampu } \\
\text { menjawab pertanyaan }\end{array}$ \\
\hline 5 & $\begin{array}{l}\text { Dapat menceritakan kembali } \\
\text { cerita yang telah didengar }\end{array}$ & 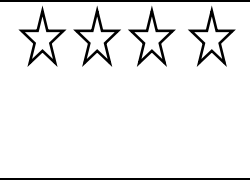 & $\begin{array}{l}\text { Anak mampu } \\
\text { menceritakan kembali } \\
\text { cerita yang didengar } \\
\text { sesuai dengan alur cerita }\end{array}$ \\
\hline
\end{tabular}




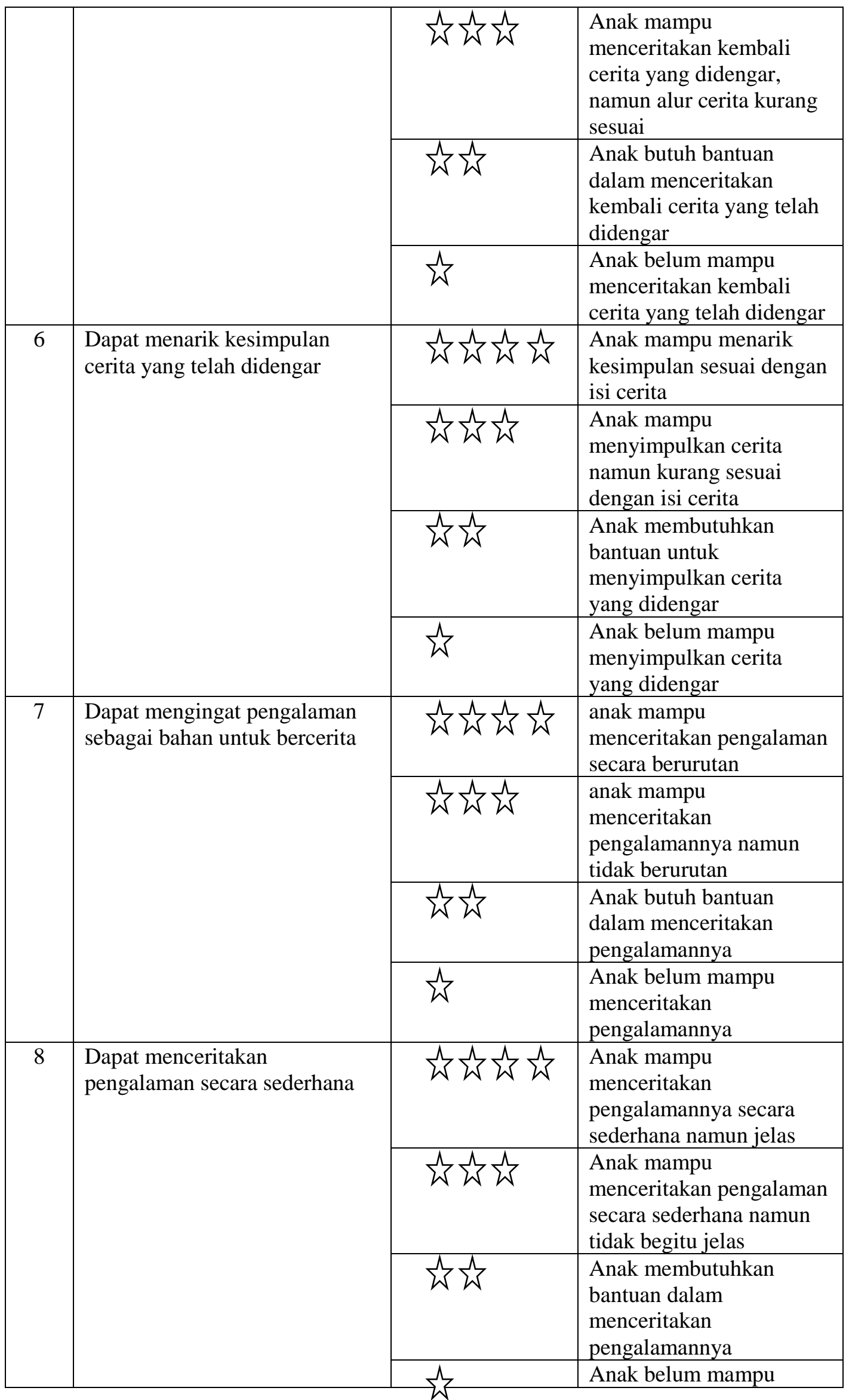




\begin{tabular}{|c|c|c|c|}
\hline & & & $\begin{array}{l}\text { menceritakan } \\
\text { pengalamannya }\end{array}$ \\
\hline \multirow[t]{4}{*}{9} & \multirow[t]{4}{*}{$\begin{array}{l}\text { Dapat melengkapi kalimat yang } \\
\text { dimulai guru dengan benar }\end{array}$} & 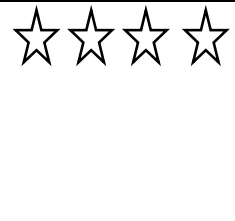 & $\begin{array}{l}\text { Anak mampu } \\
\text { menyambung cerita yang } \\
\text { dimulai dengan kalimat } \\
\text { dari guru dengan topik } \\
\text { yang sama }\end{array}$ \\
\hline & & $\hat{\alpha} \boldsymbol{\alpha}$ & $\begin{array}{l}\text { Anak mampu } \\
\text { menyambung cerita yang } \\
\text { dimulai dengan kalimat } \\
\text { dari guru namun tidak } \\
\text { sesuai dengan topic }\end{array}$ \\
\hline & & 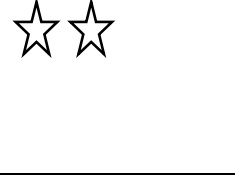 & $\begin{array}{l}\text { Anak membutuhkan } \\
\text { bantuan dalam } \\
\text { menyambung cerita yang } \\
\text { dimulai dari guru }\end{array}$ \\
\hline & & $\hat{\alpha}$ & $\begin{array}{l}\text { Anak belum mampu } \\
\text { menyambung cerita yang } \\
\text { dimulai dari guru }\end{array}$ \\
\hline
\end{tabular}

Pengujian Wilcoxon yang digunakan dalam penelitian ini adalah uji Wilcoxon Match Pairs Test, Sugiyono(174:2015). Uji ini melibatkan satu populasi penelitian yaitu TK Aisyiyah 33 Surabaya dan kelompok A2 sebagai sampelnya. Perbandingan selisih akan diuji menggunakan hasil pretest dan postest untuk mengetahui peringkatperingkatnya.

\section{HASIL PENELITIAN}

Data yang digunakan dalam penelitian mengenai kemampuan bercerita anak usia dini ini diambil dari hasil observasi yang terdiri dari 5 indikator, diantaranya ekspresi wajah, tanya jawab, mengulang kalimat yang sudah didengar, bercerita tentang pengalaman anak dan melengkapi kalimat yang sudag dimulai guru. Observasi ini dilakukan ketika pretest dan posttest. Pretest dilakukan sebelum pemberian perlakuan (treatment) pada kelompok A2. Sedangkan Posttest dilakukan setelah diberikannya perlakuan (treatment).

Adapun hasil pretest dan posttest dapat disajikan sebagai berikut: 
PENGARUH MEDIA PICK ME TERHADAP PERKEMBANGAN KECERDASAN VERBAL LINGUISTIK ANAK USIA DINI

\section{Tabel 4}

\section{Hasil Pretest}

\begin{tabular}{|c|c|c|c|c|c|c|c|c|}
\hline \multirow[t]{2}{*}{ No } & \multirow[t]{2}{*}{ Nama } & \multicolumn{5}{|c|}{ Indikator Perkembangan Bahasa Usia 4-5 Tahun } & \multirow[b]{2}{*}{$\begin{array}{c}\mathrm{J} \\
\mathrm{u} \\
\mathrm{m} \\
1 \\
\mathrm{a} \\
\mathrm{h}\end{array}$} & \multirow{2}{*}{$\begin{array}{l}\text { Rata- } \\
\text { Rata }\end{array}$} \\
\hline & & $\begin{array}{c}\text { Ekspresi } \\
\text { Wajah }\end{array}$ & $\begin{array}{l}\text { Tanya } \\
\text { Jawab }\end{array}$ & $\begin{array}{c}\text { Men } \\
\text { ceritakan } \\
\text { Kembali }\end{array}$ & $\begin{array}{c}\text { Bercerita } \\
\text { Tentang } \\
\text { Pengalam } \\
\text { an Anak }\end{array}$ & $\begin{array}{c}\text { Me } \\
\text { lengkapi } \\
\text { Kalimat } \\
\text { Yang } \\
\text { Dimulai } \\
\text { Guru }\end{array}$ & & \\
\hline 1 & Zildjian & 2 & 2 & 2 & 3 & 2 & 11 & 2.2 \\
\hline 2 & Nageeb & 2 & 2 & 2 & 2 & 2 & 10 & 2 \\
\hline 3 & Alifia & 3 & 2 & 3 & 3 & 2 & 13 & 2.6 \\
\hline 4 & Ilmi & 3 & 2 & 2 & 3 & 2 & 12 & 2.4 \\
\hline 5 & Mabi & 2 & 2 & 2 & 2 & 2 & 10 & 2 \\
\hline 6 & Nizam & 2 & 2 & 2 & 2 & 2 & 10 & 2 \\
\hline 7 & Izam & 3 & 2 & 2 & 2 & 2 & 11 & 2.2 \\
\hline 8 & Haikal & 3 & 2 & 2 & 3 & 2 & 12 & 2.4 \\
\hline 9 & Rakha & 3 & 2 & 3 & 3 & 2 & 13 & 2.6 \\
\hline 10 & Rani & 3 & 2 & 3 & 3 & 2 & 13 & 2.6 \\
\hline 11 & Angga & 3 & 3 & 3 & 3 & 2 & 14 & 2.8 \\
\hline 12 & Atika & 3 & 3 & 2 & 3 & 2 & 13 & 2.6 \\
\hline 13 & Daffa & 2 & 2 & 2 & 2 & 2 & 10 & 2 \\
\hline 14 & Tiara & 3 & 2 & 2 & 3 & 2 & 12 & 2.4 \\
\hline 15 & Alvina & 3 & 2 & 2 & 2 & 2 & 11 & 2.2 \\
\hline 16 & Revan & 3 & 2 & 2 & 2 & 2 & 11 & 2.2 \\
\hline 17 & Alicia & 3 & 2 & 2 & 2 & 2 & 11 & 2.2 \\
\hline 18 & Nauval & 3 & 2 & 2 & 2 & 2 & 11 & 2.2 \\
\hline \multicolumn{2}{|c|}{ Jumlah } & 49 & 38 & 40 & 45 & 39 & 218 & 12.1 \\
\hline
\end{tabular}

Tabel 5

Hasil Posttest

\begin{tabular}{|c|c|c|c|c|c|c|c|c|}
\hline \multirow[t]{2}{*}{ No } & \multirow[t]{2}{*}{ Nama } & \multicolumn{5}{|c|}{ Indikator Perkembangan Bahasa Usia 4-5 Tahun } & \multirow[b]{2}{*}{$\begin{array}{c}\mathrm{J} \\
\mathrm{u} \\
\mathrm{m} \\
\mathrm{l} \\
\mathrm{a} \\
\mathrm{h}\end{array}$} & \multirow{2}{*}{$\begin{array}{l}\text { Rata- } \\
\text { Rata }\end{array}$} \\
\hline & & $\begin{array}{l}\text { Ekspresi } \\
\text { Wajah }\end{array}$ & $\begin{array}{l}\text { Tanya } \\
\text { Jawab }\end{array}$ & $\begin{array}{c}\text { Menceri } \\
\text { takan } \\
\text { Kem } \\
\text { Bali }\end{array}$ & $\begin{array}{c}\text { Bercerita } \\
\text { Tentang } \\
\text { Pengalam } \\
\text { an Anak }\end{array}$ & $\begin{array}{c}\text { Me } \\
\text { lengkapi } \\
\text { Kalimat } \\
\text { Yang } \\
\text { Dimulai } \\
\text { Guru }\end{array}$ & & \\
\hline 1 & Zildjian & 4 & 3 & 4 & 4 & 3 & 18 & 3.6 \\
\hline 2 & Nageeb & 3 & 4 & 4 & 4 & 4 & 19 & 3.8 \\
\hline 3 & Alifia & 4 & 4 & 4 & 4 & 4 & 20 & 4 \\
\hline 4 & Ilmi & 4 & 4 & 4 & 4 & 3 & 19 & 3.8 \\
\hline 5 & Mabi & 3 & 4 & 4 & 4 & 3 & 18 & 3.6 \\
\hline 6 & Nizam & 4 & 3 & 3 & 4 & 4 & 18 & 3.6 \\
\hline 7 & Izam & 4 & 4 & 3 & 4 & 3 & 18 & 3.6 \\
\hline 8 & Haikal & 3 & 3 & 4 & 4 & 4 & 18 & 3.6 \\
\hline 9 & Rakha & 4 & 4 & 3 & 4 & 4 & 19 & 3.8 \\
\hline
\end{tabular}




\begin{tabular}{|l|l|l|l|l|l|l|l|l|}
\hline 10 & Rani & 4 & 4 & 4 & 4 & 3 & 19 & 3.8 \\
\hline 11 & Angga & 4 & 4 & 4 & 4 & 4 & 20 & 4 \\
\hline 12 & Atika & 4 & 4 & 4 & 4 & 4 & 20 & 4 \\
\hline 13 & Daffa & 3 & 4 & 3 & 4 & 4 & 18 & 3.6 \\
\hline 14 & Tiara & 4 & 4 & 4 & 4 & 4 & 20 & 4 \\
\hline 15 & Alvina & 4 & 4 & 4 & 4 & 3 & 19 & 3.8 \\
\hline 16 & Revan & 4 & 3 & 3 & 4 & 4 & 18 & 3.6 \\
\hline 17 & Alicia & 4 & 4 & 3 & 4 & 4 & 19 & 3.8 \\
\hline 18 & Nauval & 3 & 4 & 4 & 4 & 4 & 19 & 3.8 \\
\hline \multicolumn{2}{|l}{ Jumlah } & 67 & 68 & 66 & 72 & 66 & 339 & 19 \\
\hline
\end{tabular}

Dalam penelitian ini menggunakan uji Wilcoxon Match Pairs Test untuk menguji hipotesis nihil (Ho) yang mengatakan bahwa tidak ada pengaruh penggunaan media Pick Me terhadap perkembangan kecerdasan verbal linguistik.

Kriteria yang digunakan untuk menguji hipotesis nihil dalam penelitian ini adalah memakai taraf kesalahan 5\% atau 0,05 .

$\mathrm{H}_{0}=$ tidak ada pengaruh penggunaan media pick me terhadap perkembangan kecerdasan verbal linguistik $\mathrm{H}_{\alpha}=$ ada pengaruh penggunaan media pick me terhadap perkembangan kecerdasan verbal linguistik

Jika T hitung < T tabel maka hipotesis nol (Ho) ditolak.

Jika $\mathrm{T}$ hitung >_ $\mathrm{T}$ tabel maka hipotesis nol (Ho) tidak ditolak atau diterima.

Berikut penyajian data dalam tabel Wilcoxon Match Pairs Test.

Tabel 6

Wilcoxon Match Pairs Test

\begin{tabular}{|l|l|l|c|c|c|c|c|}
\hline No & \multirow{2}{*}{ Nama } & $\mathbf{X}_{\mathbf{A 1}}$ & $\mathbf{X}_{\mathbf{B} \mathbf{1}}$ & $\mathbf{B e d a}$ & \multicolumn{3}{|c|}{ Tanda Jenjang } \\
\cline { 5 - 8 } & & & & $\mathbf{X}_{\mathbf{B 1} \mathbf{-}} \mathbf{X}_{\mathbf{A} \mathbf{1}}$ & Jenjang & + & - \\
\hline 1 & Zildjian & 11 & 18 & 7 & 7.5 & 7.5 & 0 \\
\hline 2 & Nageeb & 10 & 19 & 9 & 18 & 18 & 0 \\
\hline 3 & Alifia & 13 & 20 & 7 & 7.5 & 7.5 & 0 \\
\hline 4 & Ilmi & 12 & 19 & 7 & 7.5 & 7.5 & 0 \\
\hline 5 & Mabi & 10 & 18 & 8 & 14 & 14 & 0 \\
\hline 6 & Nizam & 10 & 18 & 8 & 14 & 14 & 0 \\
\hline 7 & Izam & 11 & 18 & 7 & 7.5 & 7.5 & 0 \\
\hline 8 & Haikal & 12 & 18 & 6 & 2.5 & 2.5 & 0 \\
\hline 9 & Rakha & 13 & 19 & 6 & 2.5 & 2.5 & 0 \\
\hline 10 & Rani & 13 & 19 & 6 & 2.5 & 2.5 & 0 \\
\hline 11 & Angga & 14 & 20 & 6 & 2.5 & 2.5 & 0 \\
\hline
\end{tabular}




\begin{tabular}{|c|c|c|c|c|c|c|c|}
\hline 12 & Atika & 13 & 20 & 7 & 7.5 & 7.5 & 0 \\
\hline 13 & Daffa & 10 & 18 & 8 & 14 & 14 & 0 \\
\hline 14 & Tiara & 12 & 20 & 8 & 14 & 14 & 0 \\
\hline 15 & Alvina & 11 & 19 & 8 & 14 & 14 & 0 \\
\hline 16 & Revan & 11 & 18 & 7 & 7.5 & 7.5 & 0 \\
\hline 17 & Alicia & 11 & 19 & 8 & 14 & 14 & 0 \\
\hline 18 & Nauval & 11 & 19 & 8 & 14 & 14 & 0 \\
\hline \multicolumn{6}{|c|}{ Jumlah } & $\begin{array}{l}\mathrm{T}_{+}= \\
171\end{array}$ & $\mathrm{~T}_{-}=0$ \\
\hline
\end{tabular}

Diketahui bahwa Cara menentukan nilai $\mathrm{T}$ hitung adalah memilih nilai $\mathrm{T}$ yang terkecil antara nilai $\mathrm{T}_{+}$dan $\mathrm{T}_{\text {. }}$

Nilai $T_{+}=171$

Nilai $\mathrm{T}=0$

maka nilai $T_{-}=0$ ditetapkan sebagai nilai T hitung.

Cara menentukan nilai $\mathrm{T}$ tabel adalah dengan melihat tabel statistik uji Wilcoxon dengan Dari hasil analisis data dapat disimpulkan bahwa hipotesis nihil (Ho) yang menyatakan bahwa tidak ada pengaruh penggunaan media pick me terhadap kemampuan kecerdasan verbal linguistik adalah tidak benar. Dengan demikian hasil analisis data yang

\section{PEMBAHASAN}

Tahapan penelitian yang sangat dibutuhkan dalam menganalisi data adalah tahapan melakukan pretest, pemberian perlakuan, dan tahapan yang terakhir adalah posttest. Peneliti melakukan observasi awal yang disebut pretest pada kemampuan bercerita anak usia dini kelompok A melalui kegiatan bercerita tentang pengalamannya secara sederhana. taraf kesalahan 5\% atau 0,05 dan memperhatikan jumlah sampel penelitian.

Nilai $\mathrm{T}$ tabel $=40$

Jika $\mathrm{T}$ hitung $<\mathrm{T}$ tabel maka hipotesis awal $(\mathrm{H} \alpha)$ diterima dan hipotesis nihil (Ho) ditolak.

Jadi $0<40$ maka hipotesis awal $(\mathrm{H} \alpha)$ diterima dan hipotesis nihil (Ho) ditolak.

mengacu pada hasil pretest dan posttest dapat menguji kebenaran hipotesis nihil (Ho) yang ditolak sehingga menghasilkan kebenaran bahwa ada pengaruh penggunaan media pick me terhadap perkembangan kecerdasan verbal linguistik pada kelompok A TK Aisyiyah 33 Surabaya.

Hasil rata-rata nilai pretest pada kelompok A2 adalah 12.1.

Tahapan pemberian perlakuan diberikan setelah proses pretest. Tahapan ini dilakukan sebagai upaya dalam mengembangkan kecerdasan verbal linguistik pada kemampuan bercerita dengan tujuan mendapatkan hasil posttest yang diinginkan. Pemberian perlakuan ini dilakukan dalam lima tahap dengan masingmasing tahapan mengembangkan 
beberapa keterampilan yang diambil dari 5 indikator diantranya ekspresi wajah, tanya jawab, mengulang kalimat yang sudah didengar, bercerita tentang pengalaman anak dan melengkapi kalimat yang sudag dimulai guru, yang kemudian dipecah menjadi 9 butir pada rubrik penilaian. Kemampuan bercerita pada peserta didik kelompok ini berkembang bertahap pertemuan demi pertemuan, meskipun terkadang terdapat beberapa peserta didik yang justru menurun karena semangat belajarnya sedang tidak baik. Semangat peserta didik untuk belajar menjadi hal yang sangat penting untuk diperhatikan oleh orang tua maupun guru, karena memiliki pengaruh dalam menentukan perkembangan peserta didik.

Posttest sebagai proses terakhir dilakukan untuk mengetahui kemampuan bercerita pada peserta didik setelah diberikan perlakuan. Hasil posttest meningkat sangat baik dibandingkan dengan hasil pretest. Posttest mendapat hasil rata-rata 19 dari 18 peserta didik yang terlibat dalam kelompok sampel penelitian. Hasil posttest yang meningkat drastis memberikan jawaban bahwa media pick me mempengaruhi perkembangan kecerdasan verbal linguistik pada kemampuan bercerita.

Hasil analisis data yang terdiri dari data hasil pretest dan data hasil posttest yang kemudian dicari nilai selisih dari kedua proses tersebut, sehingga menghasilkan nilai-nilai jenjang yang menentukan $\mathrm{H}$ hitung untuk digunakan dalam menguji hipotesis nihil (Ho). Hasil analisis data dengan menggunakan salah satu uji wilcoxon menghasilkan nilai $T_{+}$ sebanyak 171 sementara $\mathrm{T}_{\text {- hanya }}$ bernilai 0 , data $T_{+}$memiliki arti bahwa nilai selisih dari hasil pretest dan posttest mengalami perkembangan sedangkan data $T$. berarti nilai selisih antara kedua proses pengambilan data mengalami penurunan. Dari nilai kedua $\mathrm{T}$ untuk menentukan nilai $\mathrm{T}$ hitung adalah dengan memilih nilai $\mathrm{T}$ yang terkecil yaitu $T_{\text {- }}$ yang bernilai 0 dan dibandingkan nilai terkecil dengan $\mathrm{T}$ tabel yang diambil dari tabel statistik uji Wilcoxon yang bernilai 40, sehingga hasilnya menyatakan bahwa hipotesis nihil ditolak dan dapat disimpulkan bahwa terdapat pengaruh penggunaan media pick me terhadap perkembangan kecerdasan verbal linguistik.

Berhasilnya penelitian ini menjawab teori yang dikemukakan oleh Soeparno (1987:19) bahwa media gambar seri merupakan media pandang yang termasuk kedalam salah stau jenis media nonproyeksi. Media ini terbuat dari kertas manila lebar yang berisi beberapa gambar yang saling berhubungan satu sama lain, sehingga menyerupai rangkaian cerita. Media gambar seri merupakan media yang sangat sesuai untuk melatih keterampilan ekspresi tulis (mengarang) dan ketrampilan ekspresi lisan (berbicara, bercerita). Dengan mengamati gambar-gambar yang disajikan, para peserta didik diharapkan dapat memperoleh mkonsep tentang topic tertentu. Jenis 
gambar yang digunakan pada media ini merupakan gambar yang dapat menimbulkan suatu ingatan pada suatu rangkaian kejadian tertentu.

$$
\text { Berkembangnya media }
$$

pembelajaran membuat media gambar seri ini termasuk pada media pembelajaran yang sudah umum digunakan. Hal ini mendorong peneliti untuk mengembangkan media gambar seri menjadi media yang lebih menarik dengan kemasan yang baru yaitu menggunakan benda-benda replika yang berbentuk 3 dimensi sehingga akan menarik perhatian dan menimbulkan ingatan peserta didik pada kejadian-kejadin yang pernah terjadi dengan salah satu benda yang berada dalam media pick me.

\section{SIMPULAN}

Berdasarkan hasil analisis data bahwa media pick me memiliki pengaruh dalam mengembangkan kecerdasan verbal linguistik (kemampuan bercerita) kelompok A TK Aisyiyah 33 Surabaya. Media pick me dapat mempengaruhi perkembangan kecerdasan verbal linguistik, karena media pick me merupakan media yang baru dan didesain menarik supaya dapat meningkatkan ketertarikan peserta didik untuk terlibat dalam pembelajaran perkembangan kemampuan bercerita. Selain desain media menarik, benda yang berada dalam media pick me merupakan benda-benda yang berada disekitar anak. Benda-benda yang ada didalam media pick me merupakan benda replika dari motor, mobil, pesawat bola dan lain sebagainya. Penggunaan benda-benda yang berada disekitar anak memiliki tujuan untuk menstimulasi daya ingat peserta didik dalam mengingat pengalaman apa yang pernah terjadi antara peserta didik tersebut dengan salah satu benda di dalam media pick me. Dengan desain media pick me yang demikian sehingga media ini mampu mempengaruhi perkembangan kecerdasan verbal linguistik dalam kemampuan bercerita. Hasil analisis data diperoleh Thitung sebesar 0 dan Ttabel sebesar 40, karena $0<40$ maka $\mathrm{H} \alpha$ diterima dan Ho ditolak, sehingga dapat disimpulkan bahwa penggunaan media pick me mempengaruhi perkembangan kecerdasan verbal linguistik pada kemampuan bercerita anak usia dini.

\section{DAFTAR PUSTAKA}

Jasmine, J. (2007). Mengajar Dengan Metode Kecerdasan Majemuk Implementasi Multiple Intellegences, Bandung: Penerbit Nuansa.

Mustafa. (2009). Mengurai Variabel Hingga Instrumentasi, Yogyakarta: Graha Ilmu.

Noor, J. (2011). Metodologi Penelitian: Skripsi, Tesis, Disertasi, dan Karya Ilmiah, Jakarta: Kencana.

Sugiyono. (2015). Statistik Nonparametris Untuk Penelitian, Bandung: Alfabeta. 
Nidia Mufidati ${ }^{1}$, Ratno Abidin ${ }^{2}$, Naili Sa'ida ${ }^{3}$

Soeparno. (1987). Media Pengajaran

Bahasa, Yogyakarta: PT. nsan

Pariwara. 